\title{
TŁUMACZENIA I RECEPCJA W EUROPIE I TURCJI PRAC JUDY TADEUSZA KRUSIŃSKIEGO SI O WOJNIE AFGAŃSKO-PERSKIEJ I UPADKU DYNASTII SAFAWIDÓW
}

\author{
Ryszard Skowron (D) http://orcid.org/0000-0001-9131-2832 \\ Uniwersytet Śląski w Katowicach
}

\begin{abstract}
EUROPEAN AND TURKISH TRANSLATIONS AND RECEPTION OF WORKS BY JUDA TADEUSZ KRUSIŃSKI SI REGARDING THE AFGHAN-PERSIAN WAR AND THE FALL OF THE SAFAVID DYNASTY
\end{abstract}

This article discusses the process of developing, editing and translating a Latin text written by the Polish Jesuit J.T. Krusiński dedicated to the reasons behind the fall of the Safavid dynasty and to the course of the Afghan-Persian War. The first manuscript was titled by the author as Historia revolutionis persicae. The Latin text, which was prepared in Rome, was then sent to Paris where it wasnot only translated into French, but also significantly modified and shortened by A. du Cerceau. The French paraphrase, published in 1728, became the basis for the English and Italian editions. Another version of Krusiński's work was prepared and published in German by J. Stöcklein. He used not only the French edition, but also the Latin original of Krusiński's text, which he had received from Vienna, as well as other sources. For the needs of the Ottoman court, Krusiński reviewed the Latin version, which was then translated and published in Turkish in 1729. This last edition caused a sharp dispute over the authorship of the Turkish translation between Krusiński and Ibrahim Mütaferrika, head of the Istanbul printing house. The Turkish edition of Father Juda Tadeusz Krusiński's work complicated its reception in Europe even more, especially after the Turkish version had been retranslated into Latin by J.Ch. Clodius. The manuscripts stored in the Vienna library make it possible to trace the stages of developement of Krusiński's work, which culminated in the publication of the book Tragica vertentis ... (Lviv, 1740), his most comprehensive study of the Persian revolution.

Keywords: Juda Tadeusz Krusiński, Persia, Safavid dynasty, Afghan-Persian War, early modern translation.

Słowa kluczowe: Juda Tadeusz Krusiński, Persja, Safawidzi, wojna afgańsko-perska, translatoryka nowożytna. 
Atak Afganów na Isfahan w 1722 roku, walka Safawidów o utrzymanie tronu oraz interwencja Turcji i Rosji na Kaukazie i wybrzeżu Morza Kaspijskiego spowodowały znaczny wzrost zainteresowania Persją w całej Europie. W ciągu następnych trzech dekad XVIII wieku gwałtowanie zwiększyła się liczba publikacji ukazujących przebieg wydarzeń w Azji Południowo-Zachodniej. W tym czasie ogólnoeuropejską popularność zdobyły książki polskiego jezuity Judy Tadeusza Krusińskiego, który w latach 1706-1725 przebywał w Persji. Przedstawił w nich przyczyny upadku dynastii Safawidów oraz dzieje wojny afgańsko-perskiej.

Polskie badania nad życiem i twórczością Krusińskiego rozpoczęły się jeszcze w XIX wieku. W pierwszej kolejności należy wymienić prace Feliksa Zielińskiego, Antoniego Muchlińskiego i Stanisława Załęskiego ${ }^{1}$. Autorzy ci, opracowując swoje teksty, oparli się przede wszystkim na wydanych we Lwowie książkach misjonarza, zawierających informacje dotyczące jego pobytu w Persji. Szczególnie ważny był artykuł Muchlińskiego, wybitnego polskiego turkologa. Mimo że został opublikowany w periodyku religijno-moralnym, ma charakter naukowy, jest solidny metodologicznie, opatrzony przypisami, a autor wykorzystał publikacje zagraniczne, między innymi Giambatistty Toderiniego i Johna Malcolma. Następne pokolenia badaczy w niewielkim zakresie pogłębiły wiedzę na temat życia ojca Judy Tadeusza. Ważny, wydany w 1935 roku, syntetyczny artykuł Stanisława Brzezińskiego, dotyczący relacji Rzeczypospolitej z Persją i działalności misjonarzy polskich w tym kraju, nie przyniósł nowych danych dotyczących pracy misyjnej Krusińskiego, ale mocniej powiązał ją z działaniami dyplomacji polskiej². Opublikowany w Polskim Słowniku Biograficznym przez Bronisława Natońskiego biogram Krusińskiego nie wniósł już nowych wiadomości o jego pobycie w Persji, autor pominął też niektóre fakty zawarte we wcześniejszych pracach ${ }^{3}$.

W ciągu następnych bez mała 50 lat osobę Krusińskiego i jego dzieła omawiali badacze zajmujący się dziejami polskiej orientalistyki, relacjami Rzeczypospolitej z Persją i Turcją czy pobytem Polaków na Kaukazie, ale artykułów o charakterze monograficznym lub prac zawierających bardziej rozbudowane informacje o działalności misjonarza ukazało się zaledwie kilka. Wymienić należy przede wszystkim prace: Bohdana Baranowskiego, Jana Reychmana, Dawida Kolbaji, Stanisława W. Popławskiego, Mikołaja P. Borkowskiego, Dariusza Kołodziejczyka, ukraińskiej badaczki Iriny Ciborowskiej-Rymanowicz oraz angielskiego orientalisty Laurence'a Lockharta i amerykańskiego badacza Rudiego Matthee ${ }^{4}$. W zdecydowanej większości prace

1 F. Zieliński, Xsiądz Krusiński. Wiadomości historyczne, „Biblioteka Warszawska” 1844, t. 4, s. 375-397; A. Muchliński, Materiały do dziejów kościoła polskiego z języków wschodnich, „Pamiętnik Religijno-Moralny" 1861, t. 31, nr 8, s. 134-151, nr 9, s. 289-302; S. Załęski, Misje w Persji w XVII i XVIII wieku pod protektoratem Polski, Kraków 1882; idem, Jezuici w Polsce, t. III, cz. II, Lwów 1902 , s. 859-892.

2 S. Brzeziński, Misjonarze i dyplomaci polscy w Persji $w$ XVII i XVIII wieku, Potulice 1935 (odbitka z „Annales Missiologicae” 1935, t. 7).

3 B. Natoński, Krusiński Jan Tadeusz [w:] Polski Słownik Biograficzny, t. 15, Wrocław 1970, s. $426-428$.

4 J. Reychman, Znajomość i nauczanie języków orientalnych w Polsce, Wrocław 1950, s. 33-38; B. Baranowski, Znaczenie relacji Tadeusza Krusińskiego dla historii Gruzji pierwszej połowy XVIII 
te, podobnie jak inne, nie weryfikowały ustaleń badaczy z XIX i pierwszej połowy $\mathrm{XX}$ wieku, a część autorów formułowała tezy nieoparte na badaniach źródłowych ${ }^{5}$.

Osobnym tematem badawczym są thumaczenia łacińskich prac Krusińskiego oraz ich edycja w Europie i Turcji w XVIII wieku. Już Muchliński w drugiej części artykułu omówił lwowskie książki jezuity, wymienił przekłady jego prac i ich edycje w Europie i Turcji. Późniejsi badacze opierali się na wykazie prac misjonarza zawartym w tomie 20 Bibliografii Estreichera. Dopiero Popławski, omawiając rękopis kórnicki (zob. dalej), nieco więcej miejsca poświęcił europejskim wydaniom pracy Krusińskiego. Ostatnio badania nad twórczością pisarską ojca Judy Tadeusza pogłębił autor niniejszego artykułu, analizując jego wkład w europejskie poznanie Kaukazu i Persjí.

wieku, „Folia Historica” 1981, 10, s. 21-33; B. Baranowski, K. Baranowski, Polaków kaukaskie drogi, Łódź 1985, s. 41-46; D. Kolbaja, Juda Tadeusz Krusiński - misjonarz, uczony dyplomata. Życie i dzieło, „Pro Georgia” 1992, z. 2, s. 19-27; S.W. Popławski, Wielki nieznany - o. Tadeusz Krusiński S.J. - misjonarz, dyplomata, pisarz, uczony, „Studia Bobolana” 2015, t. 2, s. 105-126; M.P. Borkowski, The Writings of Tadeusz Juda Krusiński's and the Image of Iran in some 18th Century Polish Printed Geographical Compendia [w:] Irān va Lahestān. Munāsabāt-e farhangi va tamaddoni / Historical and Cultural Interactions of Poland and Iran, eds. D. Kołodziejczyk, H. Kazemzadeh, Tehran 1396/2016, s. 15-25; I. Ciborowska-Rymanowicz, Orientalista Tadeusz Krusiński (1675-1757) i egzemplarze jego prac w bibliotekach klasztornych i prywatnych XVIII wieku, „Bibliotekarz Podlaski” 2015, t. 16, nr 1, s. 11-34; L. Lockhart, The Fall of the Safavi Dynasty and the Afghan Occupation of Persia, London 1958, s. 516-525; R. Matthee, Introduction [w:] J.T. Krusinski, The History of the Revolution of Persia: An Eyewitness Account of the Fall of the Safavi Dynasty, Tauris 2018, s. VII-XVII (ten wybitny badacz dziejów Iranu często w swoich pracach odwołuje się do anglojęzycznego wydania książki Krusińskiego, np. w: idem, Persia in Crisis: Safavid Decline and the Fall of Isfahan, LondonNew York 2012, s. 184-219.

${ }^{5}$ Dobrym przykładem jest nieoparty na źródłach pogląd o pobycie polskiego jezuity w Afganistanie. Taka informacja pojawiła się w artykule: B. Chwaściński, Hindukusz. Dzieje poznania, „Taternik” 1962, nr 2-4, s. 58. B. Chwaściński błędnie przypisał Krusińskiemu autorstwo wydanej w 1741 r. książki zatytułowanej Histoire de Thamas Kouli-Kan Sophi de Perse i zacytował z niej, bardzo nieprecyzyjnie, fragmenty opisu tych gór. I chociaż Chwaściński nigdzie wprost nie stwierdzał, że jezuita przebywał w Afganistanie, to część badaczy uznaje to za wystarczający dowód jego podróży po tym kraju. Wspomnieć tu należy zwłaszcza o J. Fedirko, który wykorzystując w sposób wtórny źródła oraz pomijając dorobek uczonych polskich i zagranicznych, propaguje ten pogląd. Zob. J. Fedirko, Afganistan w polskich badaniach naukowych, „Krakowskie Studia Międzynarodowe” 2007, nr 1, s. 212-213; idem, Pierwszy informator Europy o Afganach. Ojciec Tadeusz Krusiński: krakowski uczony, misjonarz, „Alma Mater” 2007, nr 93, s. 83-86.

${ }^{6}$ R. Skowron, La contribución de Tadeusz Krusiński S.I. al conocimiento de Persia y del Cáucaso en Europa. La circulación de la información y propiedad intelectual en el siglo XVIII [w:] Eastern Europe, Safavid Persia and the Iberian World: Frontiers and Circulations at the Edge of Empires, eds. J. Cutillas Ferrer, O. Recio Morales, Valencia 2019, s. 59-79. 


\section{ŁACIŃSKIE KSIĄŻKI KRUSIŃSKIEGO}

Po powrocie do Polski w 1729 roku Krusiński wydał dwie książki poświęcone Persji, z których jedna miała trzy wydania. Zostały one opublikowane w drukarni kolegium jezuickiego we Lwowie. Pierwsza z nich, pod tytułem Prodromus ad historiam revolutionis Persicae seu legationis Fulgide Porte ad Persarum Regem..., ukazała się w $1733 \mathrm{roku}^{7}$. Rękopiśmienny tekst tej pracy został przygotowany przynajmniej trzy lata wcześniej, o czym świadczy zamieszczona w książce aprobacja Jana Juśkiewicza, prepozyta prowincji polskiej Towarzystwa Jezusowego, wystawiona 13 lipca 1730 we Lwowie. Nie znamy powodów tak dużego opóźnienia druku. W 1734 roku ukazało się drugie wydanie tej pracy pod nieco zmienionym tytułem: Prodromus ad tragicam vertentis belli Persici historiam seu Legationis a Fulgida Porta ad Sophorum Regem ... ${ }^{8}$. Najprawdopodobniej druga edycja była związana z niewielkim nakładem książki z 1733 roku9. Zasadnicza część pracy, zatytułowana Legationis Turcico-Persicae relatio ex textu turcico latine ita sinat, to thumaczenie z języka tureckiego relacji z misji, którą w 1720 roku na dwór szacha perskiego odbył Durri Efendi, poseł sułtana Ahmeda III. Tłumaczenia tekstu tureckiego dokonał jezuita jeszcze w czasie pobytu w Konstantynopolu i związane ono było z projektem Damada Ibrahima Paszy, który zamierzał zorganizować szkołę dragomanów. Obie edycje w głównej części są identyczne, mają bowiem tę samą czcionkę i interlinie, takie same łamanie wierszy i błędy literowe, tę samą liczbę stron numerowanych. Różnią je tylko: nieco zmieniony tytuł, czcionka karty tytułowej, strona z imprimatur i przede wszystkim wstęp Benvevolo lectori. W pierwszym wydaniu liczy on 9 stron, a w drugim 13. Wydany w 1733 roku Prodromus ad historiam revolutionis Persicae... praktycznie nie funkcjonuje w obiegu naukowym i dlatego najczęściej Prodromus ad tragicam vertentis belli Persici... z 1734 roku podawany jest jako pierwsze wydanie ${ }^{10}$.

7 J.T. Krusiński, Prodromus ad historiam revolutionis Persicae seu legationis Fulgide Porte ad Persarum Regem..., Leopoli 1733. (W tym i w następnych przypisach tytuły prac Krusińskiego ze względu na ich długość podajemy w wersji skróconej. Pełny ich zapis podano w bibliografii).

${ }^{8}$ Idem, Prodromus ad tragicam vertentis belli Persici historiam seu Legationis a Fulgida Porta ad Sophorum Regem..., Leopoli 1734.

${ }_{9}$ Wystawione 20 VI 1634 r. imprimatur prepozyta M. Dziewanowskiego świadczy o tym, że decyzję o ponownym druku podjęto jeszcze przed pożarem, który wybuchł we Lwowie 11 VIII 1734 r. i zniszczył część zabudowań kolegium jezuitów. Por. I. Ciborowska-Rymanowicz, op. cit., s. 18.

${ }^{10} \mathrm{~W}$ Bibliothèque des écrivains de la compagnie de Jésu (dalej: BECJ), t. II, par A. de Backer, A. de Backer, C. Sommervogel, Liége-Lyon 1872, szp. 534-535, wspomniano o druku książki w 1733 r., podano jednak tytuł z 1734 r., tak samo w: F. Babinger, Stambuler Buchwasen im 18. Jahrhundert, Leipzig 1919, s. 13. Wydania z 1733 r. nie podaje ani K. Estreicher, Bibliografia Polska, t. XX, Kraków 1905, s. 304-306, ani S.W. Popławski, op. cit., s. 112-113. Z innych prac można wymienić przykładowo: W.E.D. Allen, The Sources for G. Delisle's 'Carte des Pays Voisins de la Mer Caspiene' of 1723, „Imago Mundi” 1956, t. 13, s. 140-141. Autor ten podaje, że pierwsze wydanie Prodromus ukazało się w 1733 r., ale w przypisie stwierdza: "Krusiński's own Latin MS was only printed in 1734 in Leopolis (Lvov): Tragica vertentis belli Persici historia", robiąc podwójny błąd, ponieważ książka Krusińskiego wydana w 1734 r. miała inny tytuł, a podany przez Allena dotyczy pracy wydanej w 1740 r. Podobny błąd występuje w: M. Schwab, Bibliographie de la Perse, Paris 1875, s. 45. 
W 1740 roku ukazała się Tragica vertentis belli Persici historia per repetitas clades, ab anno 1711 ad annum 1728-vum continuata Post Gallicos, Hollandicos, Germanicos ac demum Turcicos authoris typos auctior. Authore Patre Thadaeo Krusinski Societatis Jesu Missionario Persico accessit ad eandem Historiam Prodromus iteratis typis subjectus. Książka ma aprobację arcybiskupa lwowskiego Mikołaja Wyżyckiego i prowincjała jezuitów Władysława Złotowskiego (17 maja 1739). Publikacja była klockiem wydawniczym i składała się z dwóch prac: wydanej po raz pierwszy przez samego Krusińskiego historii wojny afgańsko-perskiej, zatytułowanej Tragica vertentis belli Persici historia per repetitas clades, ab anno 1711 ad annum 1728-vum continuata..., oraz trzeciego już wydania Prodromus, które i tym razem otrzymało nieco odmienny tytuł: Prodromus ad tragicam vertentis belli historiam seu relatio turcico-persicae legationis ${ }^{11}$. Książkę otwiera obszerna dedykacja dla Stanisława Wincentego Jabłonowskiego. Tragica vertentis ... liczy 529 stron i podzielona została na trzy części. Każda z części zawiera kilka rozdziałów, a w niektórych z nich wydzielono również podrozdziały (sekcje). Najmniejszą jednostką strukturalną pracy są numerowane akapity, których jest 519. Pierwsza część (s. 1-230) stanowi analizę wewnętrznych przyczyn upadku monarchii perskiej. Krusiński ukazuje, jak od okresu panowania Abbasa I stopniowo postępował proces osłabiania władzy centralnej, narastania partykularyzmów i walk frakcyjnych, które swoje apogeum osiągnęły za rządów szacha Sułtana Husejna. W drugiej części (s. 231-425) jezuita omawia przebieg wojny afgańsko-perskiej od buntu Mir Waisa aż do objęcia tronu przez szacha Aszrafa. Zamyka ją Appendix zawierający informację o liczebności wojsk afgańskich w trakcie prowadzenia różnych operacji wojennych. Trzecią część (s. 426-513) Krusiński poświęcił czterem wojnom, które w konsekwencji doprowadziły do upadku monarchii perskiej: gruzińsko-perskiej, Moskwy z Lezgami, turecko-perskiej i turecko-afgańskiej. Książkę zamyka zakończenie zatytułowane Problema. Autor przedstawił w nim własną ocenę sytuacji w Persji pod koniec lat 20. XVIII wieku, $\mathrm{z}$ niewielkimi odniesieniami do lat 30 .

Część bibliografii wymieniających publikacje Krusińskiego podaje, że w 1755 roku opublikował on Analecta ad tragicam belli persici historiam ... ${ }^{12}$, ale nie udało się ich odnaleźć w zbiorach żadnej biblioteki. Informację o tej książce przyjęto z wydanego w 1755 roku leksykonu Jana D. Janockiego, który podaje, że właśnie drukuje się ona u jezuitów we Lwowie ${ }^{13}$. Krusiński tej książki zapewne nie ukończył przed swoją śmiercią, ale 12 lat po jego zgonie ukazała się napisana w języku polskim broszura na temat picia kawy tureckiej ${ }^{14}$.

${ }^{11}$ Należy zwrócić uwagę na kilka błędów, jakie występują w artykule S.W. Popławskiego (op. cit., s. 112-113). Badacz ten uważa Tragica vertentis belli Persici za drugą, łacińską wersję Prodromus i nie podaje informacji, że trzecie wydanie tej ostatniej pracy było częścią klocka wydanego w 1740 r. Powtórzona za T. Kowalskim informacja o przetłumaczeniu Prodromus z łaciny na język turecki (!) i wydaniu tej pracy w Konstantynopolu w 1729 r. pod tytułem Terdżumet-i-ta 'rich-i-sajj'ah również jest błędna.

12 Zob. np. BECJ, t. II, szp. 535; M. Schwab, op. cit., s. 45; K. Estreicher, op. cit., s. 305.

13 J.D. Janocki, Lexicon derer itztlebenden Gelehrten in Polen, t. II, Breslau 1755, s. 184.

${ }^{14}$ T. Krusiński, Pragmatographia de legitimo usu ambrozji tureckiej: To jest opisanie sposobu należytego zażywania kawy tureckiej..., Warszawa 1769. 


\section{DU CERCEAU I FLEURIAU: FRANCUSKOJEZZYCZNA PARAFRAZA}

Żadna z wydanych przez Krusińskiego we Lwowie łacińskojęzycznych prac nie została nigdy przetłumaczona na inne języki i nie stała się podstawą jego europejskiej popularności. Kiedy jednak w 1733 roku publikował pierwszą książkę, jego historia ukazująca ostatnie lata rządów dynastii Safawidów i opanowanie Persji przez Afganów funkcjonowała już w obiegu literackim i naukowym właściwie w całej Europie i Turcji.

We września 1725 roku przebywający w Dżulfie Krusiński z polecania Barnaby de Milano, biskupa Isfahanu, udał się do Rzymu, aby tam zdać sprawozdanie z rozpaczliwego położenia, w jakim znalazły się misje katolickie w Persji na skutek trwającej od prawie trzech lat wojny ${ }^{15}$. Udając się w drogę, jezuita dołączył do poselstwa szacha Aszrafa do Turcji. W drugiej połowie stycznia 1726 roku wraz z ambasadorem Abd al-Azizem dotarł do Konstantynopola, skąd zapewne wkrótce wyruszył do Włoch. W Rzymie przygotował dla Kongregacji Propagandy Wiary sprawozdanie w języku łacińskim dotyczące położenia misji katolickich na terenie Persji i sytuacji wewnętrznej w tym kraju. Często w literaturze bywa ono utożsamiane z pierwotną wersją jego historii wojny afgańsko-perskiej, zatytułowaną Relatio de mutationibus Regni Persarum, która miała zostać wydana w Rzymie w 1727 roku. Informację tę podano w wydawnictwie A. Backera i C. Sommervogel, ale autor biogramu Krusińskiego, wymieniając książkę, od razu zastrzega: ,je n'ai pas recontré cette pièce" ${ }^{16}$. Do dziś publikacja ta nie została odnaleziona. Ze względów formalnych sprawozdania przygotowanego dla Kongregacji nie można jednak utożsamiać z późniejszą książką.

Zapewne po uzyskaniu zgody Kongregacji Propagandy Wiary na kontynuowanie działalności misyjnej Krusiński przybył w 1727 roku do Konstantynopola, skąd miał wyruszyć do Persji ${ }^{17}$. Z powodu trwającej wojny turecko-perskiej nie mógł jednak podjąć dalszej podróży i jego pobyt w Turcji trwał kilkanaście miesięcy ${ }^{18}$.

Kiedy Krusiński przebywał w Konstantynopolu, w Paryżu i Hadze w 1728 roku, została opublikowana dwutomowa, francuskojęzyczna książka zatytułowana Histoire de la dernière révolution de Perse ${ }^{19}$. Karta tytułowa wydawnictwa nie zawiera

${ }^{15}$ W Tragica vertentis..., s. 22-24 (list bpa Barnaby de Milano do kardynała Giuseppe Sacripante, Dżulfa, 30 VIII 1725).

${ }^{16}$ BECJ, t. II, s. 535, zapewne z niej informacja o Relatio de mutationiubs trafiła do innych bibliografii, np. M. Schwab, op. cit., s. 45; K. Estreicher, op. cit., s. 306. Zob. też L. Lockhart, op. cit., s. 518 (autor pisze o bezskutecznych poszukiwaniach tej książki).

${ }^{17}$ Krusiński w pierwszym zdaniu Benvevolo lectori w Prodromus..., 1733, 1734 pisze: „Dum Constantinopoli, Anno 1727, remeandi in Persidem commoditatem opperiendo...”. Niestety nigdzie nie podaje przybliżonej daty przybycia do stolicy Turcji.

${ }^{18}$ Podawana w polskich opracowaniach informacja o pobycie Krusińskiego w Persji w 1727 r. i o przyjęciu go na audiencji przez szacha w Isfahanie 11 VI tegoż roku, zawarta w artykule: F. Zieliński, op. cit., s. 382, jest nieprawdziwa i wynika zapewne z błędu drukarskiego, ponieważ do opisywanych wydarzeń doszło w 1721 r., por. J.T. Krusiński, Prodromus..., 1734, p. 323. Za Zielińskim informację tę powtórzyli m.in.: S. Brzeziński, op. cit., s. 69; S.W. Popławski, op. cit., s. 110.

19 J.T. Krusiński, Histoire de la dernière révolution de Perse, t. 1-2, Paris: Briasson 1728; La Haye: Gosse et Neulme 1728. 
żadnych danych o autorze, thumaczu czy wydawcy. Aprobata wystawiona 18 listopada 1727 roku podaje jedynie tytuł książki i nazwisko Antoine'a-Claude'a Briassona, paryskiego edytora-księgarza. W historiografii dominuje pogląd, że thumaczem i wydawcą tej pracy był jezuita francuski Antoine Du Cerceau (1670-1730), poeta, dramaturg, jeden z redaktorów „Journal de Trévoux” ${ }^{20}$. W obszernym wstępie, już na drugiej stronie, wydawca podał następującą informację: „L'Histoire que je donne au public est fondée sur un témoignage de cette nature, puisque je l'ai composé uniquement sur les Memoires du Pere Jude Krusinski Jesiute Polonois, qui après avoir demeuré vingt ans à Ispahan"21, a dalej przedstawił kilka podstawowych informacji o autorze i jego dziele oraz charakterystykę zmian, jakie wprowadził w stosunku do rękopisu, który otrzymał. Najważniejszą z nich była modyfikacja struktury pracy, polegająca na przeniesieniu na początek książki i skróceniu trzeciej, najobszerniejszej części, opisującej przyczyny dezorganizacji państwa perskiego w czasach szacha Husejna. Du Cerceau uważał bowiem, że taka zmiana układu uporządkuje pracę chronologicznie i ułatwi czytelnikowi zrozumienie opowiadanej historii. Wyjaśnił, że tekst jezuity polskiego zawiera dzieje wojny afgańsko-perskiej do końca roku 1725, a on je rozszerzył do $1727 \mathrm{roku}^{22}$. Edycja francuska nie ma podziału na rozdziały. Jedynie w drugiej części Przedmowy wydawcy wydzielone zostały podrozdziały, w których przedstawiono dzieje panowania poszczególnych władców Persji z dynastii Safawidów. Histoire de la dernière... ukazała się w połowie roku 1728 (być może w maju), na co wskazuje list z Konstantynopola z 29 lipca 1728 zamieszczony na łamach wrześniowego „Mercure de France”23, którego autor donosił, że książka ta dotarła już wówczas do stolicy Turcji. We wrześniowym numerze „Journal de Trévoux” znalazło się z kolei jej obszerne, liczące siedem stron streszczenie ${ }^{24}$. Została ona omówiona także na łamach „Le Journal des sçavans” ${ }^{25}$. W żadnym z tych artykułów nie pojawiło się nazwisko Du Cerceau jako thumacza i wydawcy. Autorzy, odwołując się do wstępu książki, podają, że powstała ona na podstawie wspomnień ojca Krusińskiego. $\mathrm{Du}$ Cerceau w przedmowie informuje, że pracę Polaka przekazał mu jezuita Thomas Ch. Fleuriau d'Armenonville ${ }^{26}$, protektor misji francuskich w Lewancie i zasłużony wydawca Lettres édifiantes et curieuses. Nie precyzuje jednak, czy od ojca Fleuriau otrzymał tekst łaciński czy jego francuskie tłumaczenie. Sam Krusiński w swoich pracach jest bardzo lakoniczny w odniesieniu do francuskojęzycznego wydania $\mathrm{Hi}$ storii. W Benvevolo lectori zamieszczonym w obu pierwszych edycjach Prodromus nadmienia tylko w jednym zdaniu o przetłumaczeniu przez Du Cerceau jego Historii na język francuski, a w wydaniu z 1740 r. nazwisko jezuity francuskiego zostało już pominięte. W opublikowanych we Lwowie książkach brak jakiejkolwiek wzmianki o przekazaniu rękopisu tekstu łacińskiego Fleuriau.

\footnotetext{
${ }^{20}$ M.A. Péricaud, Essai sur la vie et les écrits de Du Cerceau, Lyon 1828.

${ }_{21}$ J.T. Krusiński, Histoire de la dernière ..., t. 1, s. II.

${ }^{22}$ Ibidem, t. 2, s. 369-370.

${ }^{23}$ „Mercure de France”, septembre 1728, s. 2098-2099.

24 ,Journal de Trévoux”, septembre 1728, s. 1613-1639.

25 „Le Journal des sçavans”, novembre 1728, s. 682-691.

26 J.T. Krusiński, Histoire de la dernière..., Paris 1728, s. XIV.
} 
Krusiński przybył do stolicy imperium otomańskiego, gdy wielki wezyr Damad Ibrahim Pasza organizował pierwszą turecką drukarnię, której powstanie uważa się za jedno z najważniejszych osiągnięć związanych z procesem okcydentalizacji kultury tureckiej w tak zwanym okresie tulipanów (1718-1730), i planował otwarcie szkoły dragomanów. W obu tych projektach polski jezuita odegrał ważną rolę. Kilka krótkich informacji zawartych w pracach Krusińskiego i podanych przez Louisa André de La Mamie de Clairac we wstępie do wydanej w 1750 roku Histoire de Perse ${ }^{27}$ pozwala na poznanie kontaktów towarzyskich polskiego misjonarza w Konstantynopolu. Zapewne najmocniej był związany z przebywającym na emigracji w Turcji księciem Franciszkiem II Rakoczym. Polak zatrzymał się w jego rezydencji w Rodostó $(\text { Tekirdağ })^{28}$. Joseph von Hammer-Purgstall podaje, że po śmierci ojca Jacques'a Cachoda SI Krusiński został spowiednikiem księcia ${ }^{29}$. Warto zwrócić uwagę, że polski jezuita współpracował z Rakoczym w okresie intensywnych zabiegów Węgra o rękę Marianny, córki polskiego magnata Jana Stanisława Jabłonowskiego ${ }^{30}$, którego synowi duchowny zadedykował później Tragica vertentis... Krusiński musiał dość dobrze poznać najbliższych współpracowników księcia, między innymi jego sekretarza Luisa Bechona. Zapewne utrzymywał jakieś kontakty z ambasadą francuską, bowiem z informacji zwartych w Tragica vertentis... wynika, że znał raporty (w tureckiej i włoskiej wersji językowej) na temat sytuacji w Persji, opracowane przez Josepha Apisalaimiana, sekretarza i tłumacza ambasadora wicehrabiego d'Andrezela ${ }^{31}$. Więzi przyjaźni łączyły ojca Judę Tadeusza z jezuitą francuskim Jeanem Baptistą Holdermanem, który dla drukarni stambulskiej przygotowywał francuskojęzyczne wydanie gramatyki języka tureckiego. Do kręgu bliskich znajomych zaliczyć należy również rezydenta cesarskiego przy dworze sułtana - Josefa Dierlinga ${ }^{32}$.

Podczas pobytu w Turcji w latach 1724-1727 Clairac rozpoczął zbieranie materiałów do historii Persji. Nie miał jednak możliwości spotkania się z Krusińskim, gdyż ten wyjechał z Konstantynopola kilka miesięcy przed jego przyjazdem. Natychmiast po wydaniu przez Du Cerceau Histoire de la dernière... napisał listy do Krusińskiego i Bechona, zawiadamiając ich o tym wydarzeniu. Obaj mu odpisali z Rodostó - sekretarz księcia Rakoczego 14 sierpnia, a polski jezuita 15 sierpnia $1728^{33}$. Nie znamy treści tej korespondencji. Francuski orientalista, wymieniając te listy, pisał: „Bechon travailloit alors par ordre du Prince, et sous les yeux du

${ }^{27}$ L.A. de La Mamie de Clairac, Histoire de Perse, depuis le commencement de ce siècle, t. 1, Paris 1750, s. I-XLIX.

${ }^{28}$ L. Lockhart, op. cit., s. 518; D. Kolbaja, op. cit., s. 23 (autor błędnie utożsamił Rodostó z wyspą Rodos).

${ }^{29}$ J. von Hammer, Geschichte des Osmanischen Reiches: grossentheils aus bisher unbenützten Handschriften und Archiven, vol. 7: Vom Carlowiczer Frieden bis zum Frieden von Kainardsche 16991739, Pesth 1835, s. 253.

${ }^{30}$ B. Köpeczi, A bujdosó Rákóczi, Budapest 1991, s. 408-412.

31 J.T. Krusiński, Tragica vertentis..., s. 353, 428. Znajomość Krusińskiego z Josephem pośrednio potwierdza również La Mamie de Clairac, op. cit., s. IX.

${ }^{32}$ B. Köpeczi, op. cit., s. 405.

${ }^{33}$ L.A. de La Mamie de Clairac, op. cit., s. LI, LVI. 
P. Krusinski, à la traduction françoise des Mémoires de ce Missionnaire"34. Na podstawie tej informacji Clairaca L. Lockhart postawił tezę, że to Bechon przetłumaczył na francuski pracę ojca Judy Tadeusza, którą ten wysłał do Fleuriau ${ }^{35}$. Teza ta budzi, z kilku zasadniczych powodów, bardzo duże wątpliwości i należy ją odrzucić. Nie ulega bowiem żadnej wątpliwości, że z Rzymu do Francji przesłany został rękopis w języku łacińskim, ponieważ Krusiński pisał: „Ubi Historia haec, quam duntaxat Romae pro versione Gallica latine conscripseram, Gallice Parisiis prodiit" ${ }^{36}$, a w Prodromus... z 1733 roku: „quam post Gallicos, interpreter P. Cerceau”37. Lockhart nie popełniłby tego błędu, i kilku innych, jeśli wykorzystałby w swojej pracy książki wydane we Lwowie. Na obecnym etapie badań należy przyjąć, że tłumaczenia dokonał Du Cerceau, być może przy współudziale Fleuriau, który jako wydawca relacji z Lewantu miał rozległą wiedzę o rozgrywających się tam wydarzeniach, znał historię i geografię tego obszaru. Udział redaktora Lettres édifiantes et curieuses w opracowaniu wersji francuskiej wymaga dalszych, szczegółowych badań. Tym bardziej że znający znakomicie środowisko ówczesnych misjonarzy austriacki jezuita Joseph Stöcklein, wydawca Historii Krusińskiego w ramach serii Neue Welt-Bott, twierdził, że ojciec Fleuriau był tłumaczem i wydawcą paryskiej edycji ${ }^{38}$. Powyższe wyjaśnienia nie muszą stać w sprzeczności ze wzmianką Clairaca na temat francuskiego tłumaczenia Bechona. Kiedy bowiem Krusiński przybył do Rodostó, książka Histoire de la dernière... jeszcze się nie ukazała i mógł on w porozumieniu z polskim jezuitą rozpocząc thumaczenie na francuski.

\section{KRUSIŃSKI CONTRA IBRAHIM MÜTEFERRIKA. O TURECKIM WYDANIU WOJNY AFGAŃSKO-PERSKIEJ}

Z pobytem Krusińskiego w Konstantynopolu związane jest przede wszystkim wydanie w języku tureckim jego Historii wojny afgańsko-perskiej. Za pośrednictwem księcia Rakoczego informacja o tym rękopiśmiennym tekście dotarła do węgierskiego renegata Ibrahima Müteferriki, a następnie do wielkiego wezyra Damada

${ }^{34}$ Ibidem, s. LI.

${ }^{35}$ L. Lockhart, op. cit., s. 518-519. Tezę Lockharta przyjęła m.in. A.M. Touzard, French Travelers in Persia, 1600-1730, „Encyclopaedia Iranica”, 2016, http://www.iranicaonline.org/articles/france-viifrench-travelers-in-persia-1600-1730 (dostęp: 30.12.2012).

${ }_{36}$ J.T. Krusiński, Tragica vertentis..., s. 26, podobnie na s. 254.

${ }^{37}$ Idem, Benvevolo lectori [w:] Prodromus..., 1733.

${ }_{38}$ Der Neue Welt-Bott oder Allerhand So Lehr-als Geist-reiche Brief, Schrifften und Reis-Beschreibungen, Welche von denen Missionariis der Gesellschaft Jesu aus Weit-entfernten Ländern biß Anno 1730. in Europa angelangt seynd. Jetzt zum erstenmal verteutscht und vielfaltig verbessert von P. Josepho Stöcklein, gedachter Societät Priestern Achtzehender Theil. Von numero 394. biß numero 410. Begreifft in sich R.P. Judae Thaddaei Krusiński è S.J. und des Herrn Durri Effendi, Nachrichten von der letzten Unruhe in Persian, Augspurg 1732, s. 1. 
Ibrahima Paszy ${ }^{39}$. Na potrzeby edycji tureckojęzycznej Krusiński musiał opracować nową wersję pracy, ponieważ tylko dostosowanie się do odbiorcy tureckiego stwarzało możliwość druku. Na ten temat pisał tak: „Et quidem in versione Turcica id unicum verebar, ne generosi et civilissimi genii Persarum comparatio, Osmanensium sugillare videretur barbariem" ${ }^{40}$. Sprawa była o wiele bardziej skomplikowana. Historię bowiem należało tak opracować, aby żadnym słowem nie urazić uczuć religijnych i godności Turków. W dotychczasowych badaniach nie zwrócono uwagi na to zagadnienie. Krusiński analizował wydarzenia współczesne, rozgrywające się w skomplikowanym i skonfliktowanym układzie polityczno-religijnym. Pisał na zlecenie sunnickiego sułtana, dla którego Persja była najpotężniejszym wrogiem, o ataku sunnickich Afganów na szyickie państwo Safawidów oraz o skomplikowanej mozaice religijnej i politycznej na terenie Kaukazu. Polski jezuita miał świadomość tych wszystkich ograniczeń, ale znakomita znajomość mentalności elit imperium otomańskiego pozwoliła mu na opracowanie takiej wersji książki, która była do zaakceptowania przez Turków. W rezultacie sporządził faktograficzną, kronikarską relację z wojny, pozbawioną ocen, emocji i wartościowania chrześcijanina i misjonarza. Powstał tekst zasadniczo różniący się od pierwotnej wersji łacińskiej i francuskiej, o czym sam autor pisał tak: ,Accedebat insuper, quod in versione Turcica totum sistema latini operis immutandum esset... Quae quidem incommoda evitare, hic labor!

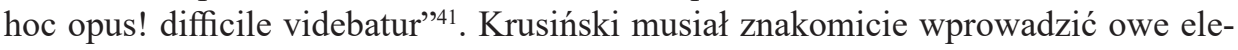
menty autocenzury, jeśli sułtan podjął decyzję o druku pracy. Drukarnia prowadzona przez Müteferrikę pod koniec sierpnia 1729 roku wydała Historię Krusińskiego pod tytułem Tārīh-i seyyāh der beyān-l zuhūr-l Afg̃ānīyan ve sebeb-i inhidām-i binā-i devlet-i şs̄hān-l Safevīyān ${ }^{42}$ w nakładzie 1200 egzemplarzy. We Wstępie Müteferrika podał, że przekładu dokonano z rękopisu łacińskiego, ale nie ujawnił nazwiska autora pracy i sobie przypisał tłumaczenie tureckie. Praca Krusińskiego to trzecia w kolejności książka wydana w drukarni stambulskiej (Ibrahim wydał ogółem 17 dzieł). Polski jezuita był jedynym europejskim autorem pracy o tematyce historyczno-politycznej ${ }^{43}$.

W momencie wydania Tārīh-i seyyāh ... misjonarz już nie przebywał w Turcji, w drogę powrotną do Polski wyruszył na przełomie listopada i grudnia 1728 roku. Rezydent cesarza Joseph Dierling w liście z 8 grudnia tego roku wysłanym do Wiednia donosił, że Krusiński pisał do niego z Adrianopola ${ }^{44}$. Duchowny dotarł do kraju zapewne na początku następnego roku, bo sam podaje w Prodromus ..., że jego pobyt na misjach trwał do roku 1729. Wkrótce po przyjeździe do Polski objął obowiązki

39 J.T. Krusiński, Prodromus..., 1733 i 1734, s. 337; idem, Tragica vertentis..., s. 27-28.

${ }^{40}$ Idem, Tragica vertentis..., s. 34.

${ }^{41}$ Idem, Prolusio [w:] Prodromus..., 1740, s. 3.

${ }^{42}$ Idem, Tārīh-i seyyāh der beyān-ı zuhūr-ı Afäānīyan ve sebeb-i inhidām-i binā-i devlet-i şāhān-l Safevìyān [Istanbul 1142/1729].

${ }^{43} \mathrm{Na}$ temat organizacji i wielkości produkcji drukarni kierowanej przez Ibrahima zob. literatura wymieniona w przyp. 59-62.

${ }_{44}$ Z. Abrahamowicz, L. Hopp, Rákóczi és török könyvnyomtatás, „Magyar Könyvszemle” 1977, vol. 93, nr 2, s. 194, przyp. 4. 
regensa w kolegium jezuickim w Kamieńcu Podolskim. Krusiński o dobiegającym końca druku tureckiej wersji Historii wojny afgańsko-perskiej dowiedział się z listu z 8 sierpnia 1729, napisanym do niego z Konstantynopola przez Holdermana ${ }^{45}$. Wraz tym listem otrzymał turecki rękopiśmienny odpis Historii, „quod ex originali utique, desumptum, submiserat mihi Constantinopoli Missionarius Soc. Jezu. R.P. Holderman"46. Najprawdopodobniej, najpóźniej w listopadzie, wraz z listem od księcia Rakoczego z 8 października dotarła do niego książka Tārīh-i seyyāh..., którą wydrukowano 26 sierpnia $1729^{47}$. To, co Krusiński przeczytał, było dla niego wielkim zaskoczeniem, wywołało gniew i sprzeciw. Taką reakcję spowodowały: niepodanie przez wydawcę autora pracy, którego ukryto pod imieniem tytułowego podróżnika, i przypisanie sobie przez Ibrahima Müteferrikę thumaczenia tekstu łacińskiego na turecki.

We wszystkich wydanych we Lwowie książkach Krusiński starał się dowieść, że to on był autorem i thumaczem Tärīh-i seyyāh ... ${ }^{48}$. Obszerne fragmenty w przedmowach do czytelnika poświęcone są przedstawieniu okoliczności powstania tureckiej wersji Historii. Z jego wyjaśnień, których część została przedstawiona powyżej, wynika, że na potrzeby thumaczenia przygotował nową wersję swojej pracy w języku łacińskim i dokonał tłumaczenia na język turecki. Za szczególnie ważne dowody potwierdzające jego autorstwo i przekład uważał wymienione listy Holdermana i księcia Rakoczego, któremu zostawił rękopis tłumaczenia tureckiego jeszcze przed wyjazdem z Konstantynopola. List księcia Siedmiogrodu wskazuje, że to Ibrahim Müteferrika zaprezentował wielkiemu wezyrowi tekst turecki, informując go, że „compositam fuisse ab uno Kara Dervis”49, czyli chrześcijańskiego zakonnika.

Krusińskiemu bardzo zależało, by praca Tārīh $i$ seyyāh ... nie pozostała anonimowa i aby zarówno tekst, jak i tłumaczenie utożsamiano z jego osobą. W egzemplarzu książki ofiarowanym Bibliotece Jagiellońskiej w Krakowie dopisał łaciński tytuł: „Historia revolutionis Monarchiae Persicae Constantinopoli pro M. Vezyrio conscripta et eiusdem iussu typis mandata opera P. Judae Krusiński Soc. Jesu Missionarii Persici" ${ }^{50}$. Do tego egzemplarza jezuita dokleił dodatkową kartę z własnoręcznie napisanym tekstem, zatytułowanym „Animadversio”, w którym zamieścił fragmenty listów Rakoczego i Holdermana. Owa nota została opublikowana przez Zygmunta Abrahamowicza i Lajosa Hoppa ${ }^{51}$.

45 J.B. Holderman do J.T. Krusińskiego, Konstantynopol, 8 VIII 1729 (fragment) [w:] J.T. Krusiński, Prodromus..., 1733 i 1734, s. 336; w wydaniu 1740, s. 27.

46 J.T. Krusiński, Prodromus... 1733 i 1734, s. 336; w wydaniu 1740, s. 27.

${ }^{47}$ Franciszek Rakoczy do J.T. Krusiński, Rodostó, 8 X 1729 (fragment) [w:] J.T. Krusiński, Prodromus..., 1733 i 1734, s. 337-339; w wydaniu 1740, s. 28; data druku książki - 1 sefera 1142 [w:] J.T. Krusiński, Tārīh-i seyyāh..., s. 97b.

${ }^{48}$ Zob. R. Skowron, op. cit. s. 67-77.

49 J.T. Krusiński, Tragica vertentis..., s. 28.

${ }^{50} \mathrm{~W}$ katalogu Biblioteki Jagiellońskiej nie jest zapisana pod tureckim tytułem Tārīh-i seyyāh, lecz łacińskim, dopisanym przez Krusińskiego: Historia revolutionis Monarchiae Persicae Constantinopoli pro M. Vezyrio conscripta ..., sygn. 586726, taki też tytuł podał K. Estreicher, op. cit., s. 306.

${ }^{51}$ Z. Abrahamowicz, L. Hopp, op. cit., s. 193-194; zob. też R. Skowron, op. cit., s. 72. 
Innym dokumentem, do którego odwołuje się Krusiński, jest aprobata druku wydana przez wielkiego muftiego. Przytacza ją w całości, zapewne z rękopisu przesłanego przez Holdermana, w thumaczeniu łacińskim. Mufti podaje w niej między innymi tytuł, jaki jezuita nadał swojej pracy: „Examinata operis huius convenientia, ab illo qui scientiae clavim habet, qui approbtionem, vel reprobationem supremo iure decernit, qui difficultatum mundi nodos solvit, ab illo inquam Antistite Antistitum, Supremo huius saeculi Iudice, populi Dei Duce, in quo sublimatae sapientiae vis, quasi cremor lacti supereminet: illius inquam approbatione mediante, Augustum Imperiale Ferman, id est mandatum, Rescriptum vel Decretum emanavit, cujus tenor qui sequitur. Decrevimus typis mandari bella gesta inter Aghvanos et Persas sub titulo Historia vertentis Revolutionis Persicae cum causis suis intrinsecis ex latino Turcice facta, opus viatoris, qui spem suam in Deo posuit"s2.

W wydrukowanej wersji Tārīh-i seyyāh ... aprobata ma treść odmienną i nie podaje żadnego tytułu. W tłumaczeniu łacińskim Clodiusa brzmi ona następująco: „Exemplum mandate Excelsi. Cum interpretationis iam memoratae generalis utilitas, et sapientia praeditis excitamento sit, ob divulgationis commode, multiplication eius per typos permissa est, et a nemine prohibienda" ${ }^{33}$. Zmiana została wprowadzona przez Müteferrikę tuż przed rozpoczęciem druku, na co wskazuje zapis, że tłumaczenie ukończono 1 zilhicce 1141, czyli 26 czerwca 1729. Komentując zgodę muftiego na druk, jezuita pisał z sarkazmem: „Et licet eiusmodi per quam honorifica approbatio Authorem operis anonimum fecerit, haud tamen conquerar: Hos ego versiculos feci, tulit alter honores, cum sine plagiarii scelere et palmaris (de quo facile vel ipso irrefragabili testimonio illius, cuius auspiciis opus illud caeperam convinci quaet) mendacii crimene, nullus istius operis sibi sumere possit honorem cum latinum authographum nulli communicaverim" ${ }^{54}$.

O ile autorstwo książki wydanej w Konstantynopolu nie wzbudza wątpliwości, o tyle od opublikowania w 1787 roku pracy Toderiniego Lettaratura Turchesca wśród badaczy zajmujących się dziejami Lewantu trwa dyskusja dotycząca osoby thumacza z łaciny na język turecki. Włoski turkolog, odwołując się do wstępu w Tārīh-i seyyāh ..., uznał Müteferrikę za autora przekładu ${ }^{55}$. Nadmienił jednak, że podczas pobytu w stolicy Turcji natrafił na wydaną we Lwowie łacińskojęzyczną książkę Krusińskiego, w której polski jezuita zarzuca Müteferrice przypisanie sobie tłumaczenia tureckiego. Pół wieku później wybitny badacz dziejów Turcji J. Hammer-Purgstall przekład wiązał z osobą ojca Judy Tadeusza ${ }^{56}$. W dziewiętnastowiecznych bibliografiach, między innymi Juliusa T. Zenkera czy Moise Schwaba, jako thumacz występuje Ibrahim Müteferrika ${ }^{57}$. Z początkiem XX wieku rozpoczęły się nowoczesne badania nad dziejami drukarstwa w Turcji. Przełomowe znaczenie miała wydana w 1919 roku

52 J.T. Krusiński, Prodromus..., 1733 i 1734, s. 336; w wydaniu 1740, s. 27.

${ }^{53}$ Idem, Tārīh-i seyyāh hoc est: Chronicon peregrinantis seu historia ultimi belli Persorum cum Aghwanis gesti..., Lipsiae 1731.

${ }^{54}$ Idem, Prodromus..., 1733 i 1734, s. 336; w wydaniu 1740, s. 27.

${ }_{55}$ G. Toderini, Lettaratura Turchesca, vol. III, Venezia 1787, s. 34-40.

56 J. von Hammer, op. cit., s. 253-254.

${ }_{57}$ J.T. Zenker, Bibliotheca orientalis. Manuel de bibliographie orientale, vol. 1, Leipzig 1846, p. 113; M. Schwab, op. cit., s. 45. 
praca Franza Babingera poświęcona działalności stambulskiej drukarni w XVIII wieku. Niemiecki orientalista, omawiając Tārīh-i seyyāh ..., wskazywał, że Müteferrika nie był na tyle biegły w łacinie, aby dokonać tłumaczenia tekstu przygotowanego przez Krusińskiego, i podał informacje o lwowskim wydaniu Tragica vertentis... ${ }^{58}$

Pomimo wątpliwości Babingera w ciągu następnych prawie 100 lat badacze zajmujący się historią stambulskiej oficyny, tacy jak Selim Nüzhet Gerçek, William J. Watson, Kemal Beydilli, Bedri Mermutlu, Yasemin Gencer, Orlin Sabev czy Efa Erginbaş, uważali Müteferrikę za tłumacza tekstu Krusińskiego ${ }^{59}$. W swoich badaniach nie wykorzystywali oni jednak łacińskich prac ojca Judy Tadeusza. Opublikowanie w 2004 roku w języku tureckim pracy Babingera przyniosło nowe refleksje na temat thumaczenia tureckiego pracy Krusińskiego ${ }^{60}$. Są one jednak jednostronne, koncentrują się bowiem tylko na udokumentowaniu i uzasadnieniu dobrej znajomości łaciny przez Ibrahima Müteferrikę, tak aby podważyć tezę niemieckiego badacza ${ }^{61}$. W niektórych opracowaniach pojawiły się jednak uwagi wskazujące na możliwość popełnienia plagiatu przez Ibrahima oraz przypominające informacje podane przez Toderiniego i Babingera ${ }^{62}$. Spośród nich należy wymienić przede wszystkim pracę bułgarskiego turkologa Orlina Sabeva, poświęconą stambulskiej drukarni, w której podrozdział dotyczący wydania Tārīh-i seyyāh badacz zatytułował: Entelektüel bir Emeğin Çalınması mı Yoksa? (Czy może kradzież pracy intelektualnej?). W omawianych badaniach nie zadawano pytania o kompetencje, jakie w zakresie języka tureckiego posiadał Krusiński. A przecież Prodromus to przede wszystkim Legationis Turcico-Persicae relatio ex textu turcico latine ita sinat. Należy również pamiętać, że jezuita był thumaczem na dworze szacha Husejna, gdzie - jak pisał - „Aulica in Perside lingua est Turcica, sed ad canones gramaticae Persicae majori gratia et emphasi inflexa. Sicut vicissim

${ }^{58}$ F. Babinger, Stambuler Buchwassen..., s. 13.

${ }^{59}$ S.N. Gerçek, Türk Matbaaciliği I. Müteferrika Matbasası, Instanbul 1939, s. 64-66; W.T. Watson, İbrahim Müteferrika and Turkish Incunabula, „Journal of the American Oriental Society” 1968, vol. 88, no. 3, s. 437; K. Beydilli, Müteferrika ve Osmanli Matbaası 18. Yüzyllda İstanbul'da Kitabiyat, „Toplumsal Tarih” 2004, nr 128, s. 46-48; B. Mermutlu, The Politic Meaning of Ottoman Printing House, „Uludağ Üniversitesi Fen-Edebiyat Fakültesi Sosyal Bilimler Dergisi” 2008, vol. 15, s. 308-309; Y. Gencer, Ibrahim Müteferrika and the Age of the Printed Manuscript [w:] The Islamic Manuscript Tradition: Ten Centuries of Book Arts in Indiana University Collections, ed. Ch. Gruber, Indiana University Press 2009, s. 161, 185; V. Erginbaş, Enlightenment of the Ottoman Context: İbrahim Müteferrika and His Intellectual Landscape [w:] Historical Aspects of Printing and Publishing in Languages of the Middle East, ed. G. Roper, Leiden-Boston 2014, s. 76-77; O. Sabev, Portrait and Self-Portrait: İbrahim Müteferrika's Mind Games, „Osmanlı Araştırmaları. The Journal of Ottoman Studies” 2014, vol. 44, s. 111-112. W tym miejscu chciałbym podziękować Pani dr hab. Marzannie Pomorskiej za pomoc w dotarciu do prac wydanych w Turcji, a Panu prof. Dariuszowi Kołodzieczykowi za cenne uwagi dotyczące wydania tureckiego pracy Krusińskiego.

${ }^{60}$ F. Babinger, ,18. Yüzyllda İstanbul'da Kitabiyat”. Müteferrika ve Osmanlı Matbaasl, ed. N.K. Burçoğlu, M. Kiel, Istanbul 2004.

${ }^{61}$ Ibidem, s. 65-70; K. Beydilli, op. cit., s. 45-49; O. Sabev, Portrait and Self-Portrait..., s. 111-112.

${ }^{62}$ M.H. van den Boogert, The Sultan's Answer to the Medici Press? Ibrahim Müteferrika's Printing House in Istanbul [w:] The Republic of Letters and the Levant, eds. A. Hamilton, M.H. van den Boogert, B. Westerweel, Leiden 2005, p. 269; O. Sabev, İbrahim Müteferrika ya da İlk Osmank1 Matabaa Serüveni (1726-1746). Yeniden Değerlendirme, Istanbul 2006. (Korzystałem z drugiego wydania z 2016 r., s. 203-205. Zob. też G. Erginbaş, op. cit. s. 76, przyp. 90). 
Constantinopoli in aula turcarum imperatoris lingua Persica in usu"63. Opierając się na łacińskich książkach, badacze polscy już od połowy XIX wieku jednoznacznie uznają Krusińskiego za tłumacza Tārīh-i seyyāh i w zasadzie nie wspominają nawet o Müteferrice. Poza pracą J. Reychmana brakuje jednak szczegółowych studiów dotyczących znajomości języków orientalnych przez polskiego misjonarza ${ }^{64}$.

Tureckie wydanie pracy ojca Judy Tadeusza jeszcze bardziej skomplikowało jej recepcję w Europie. Oto bowiem w 1731 roku w Lipsku w drukarni Johanna Gladitscha opublikowana została książka Târîh-i seyyâh, hoc est: Chronicon peregrinantis..., będąca tłumaczeniem z tureckiego na łacinę druku, który wyszedł w Konstantynopolu. Przełożył ją niemiecki arabista Johann Christian Clodius. We wstępie wyjaśnił on okoliczności, w jakich doszło do jej przetłumaczenia i wydania. Pod koniec 1730 roku do Wiednia przybył Mustafa Efendi, poseł sułtana Mahmuda I, i przywiózł ze sobą kilka egzemplarzy książek wydanych w drukarni Mütaferriki, między innymi Tārīh-i seyyāh... ${ }^{65}$. Dyplomata turecki zwrócił się wówczas do Clodiusa z propozycją retranslacji tej książki na łacinę. Ten wykonał ją bardzo szybko, bo zaledwie w przeciągu półtora miesiąca ${ }^{66}$. Clodius na podstawie listu z 20 lipca 1730 roku, przesłanego do Gladitscha przez sekretarza króla polskiego Mateusza Iliaka, sprawującego urząd gubernatora Satanowa na Podolu, uznał, że autorem Tārīh-i seyyāh ... jest Krusiński ${ }^{67}$.

W 1840 roku londyńskie wydawnictwo Jamesa Ridgweya opublikowało angielskie thumaczenie pracy Clodiusa zatytułowane The Chronicles of a Traveller, or a History of the Afghan Wars with Persia..., przygotowane przez Georga Newnhama Mitforda ${ }^{68}$. W obszernym wstępie wyjaśnił on okoliczności, w jakich niemiecki arabista dokonał przekładu tekstu Krusińskiego na łacinę. Przeprowadził również analizę porównawczą wersji tureckiej (łacińskiej Clodiusa) z Histoire de la dernière révolution de Perse. W konkluzji swoich badań stwierdził, że Tārīh-i seyyāh nie było tłumaczeniem z języka łacińskiego, lecz przerobionym tłumaczeniem francuskiej edycji Du Cerceau ${ }^{69}$. Podobną koncepcję, nie odwołując się do Mitforda, przedstawił L. Lockhart ${ }^{70}$. Stawiając taką tezę, podaje dwa argumenty. Pierwszy to podobieństwo w układzie treści między wydaniem stambulskim a paryskim, drugi zaś to tłumaczenie tekstu tureckiego na łacinę przez Clodiusa. Obaj badacze nie brali pod uwagę możliwości opracowania tekstu łacińskiego na potrzeby edycji tureckiej. Ponadto przekładu z edycji Du Cerceau na turecki nie mógł dokonać Müteferrika, ponieważ

${ }^{63}$ Ibidem, s. 145.

${ }^{64}$ J. Reychman, op. cit., s. 33-38.

${ }^{65}$ J. von Hammer, op. cit., s. 413; O. Sabev, Political and Mental Borders: Austrian-Ottoman Relations in the First Half of the Eighteenth Century and the First Ottoman-Turkish Printing Press [w:] Kommunikation und Information im 18. Jahrhundert Das Beispiel der Habsburgermonarchie, Hrsg. J. Rimmel, M. Wögerbauer, Wiesbaden 2009, s. 99.

${ }_{66}$ J.T. Krusiński, Tärīh-i seyyāh hoc est: Chronicon peregrinantis..., c. a3.

${ }^{67}$ Ibidem, c. b-bv.

${ }^{68}$ J.T. Krusiński, The Chronicles of a Traveller, or a History of the Afghan Wars with Persia..., London 1840.

${ }^{69}$ Ibidem, s. XL-XLI.

${ }^{70}$ L. Lockhart, op. cit., s. 522; tak samo: A.M. Touzard, op. cit. 
nie znał on francuskiego. Sekretarz ambasady francuskiej w Konstantynopolu Charles de Peyssonnel pisał w jednym ze swoich listów z 1738 roku, że rozmawiał z nim po łacinie, a użyte przez niego sformułowanie „,iznął łaciny” (,il a conservé quelque teinture de la langue latine") $)^{71}$ wskazuje na słabą znajomość tego języka przez Ibrahima. Tłumaczenie dokonane przez Clodiusa świadczy o tym, że Turcy nie posiadali łacińskiego tekstu Krusińskiego. W związku z tym nasuwa się pytanie - na podstawie czego Müteferrika dokonał tłumaczenia? Potwierdza to również informację podaną przez Krusińskiego, który zarzucając plagiat kierownikowi drukarni, stwierdzał, że wyjeżdżając z Turcji, nikomu nie zostawił łacińskiej wersji pracy: „cum latinum authograhpum nulli communicaverim"72.

\section{TŁUMACZENIA FRANCUSKIEJ EDYCJI}

Jeszcze w 1728 roku Histoire de la dernière révolution de Perse została przetlumaczona na język angielski i wydana w Londynie przez Johna Pembertona pod tytułem: The History of the Revolution of Persia ${ }^{73}$. W edycji tej podano w tytule zarówno nazwisko Krusińskiego jako autora, jak i Du Cerceau jako wydawcy. Miało to duże znaczenie nie tylko dla jednoznacznego powiązania Historii wojny perskiej z nazwiskiem polskiego jezuity, ale również dla funkcjonowania, w następnych stuleciach, autorstwa tego dzieła w obiegu naukowym i intelektualnym angielskiego obszaru językowego. Dodajmy, że thumaczenie z języka francuskiego jest wierne, wydawca zachował oryginalne akapity, zrezygnował z części przypisów, włączając niektóre z nich w tekst główny. Mimo że w tytule wymieniono relacje Jeana B. Taverniera, Jeana Chardina $\mathrm{i}$ innych, to zakres ich wykorzystania jest identyczny jak w tekście francuskim. Ponadto wydawca dołączył mapę Persji wraz z jej opisem. W następnym roku książka ta, poszerzona o krótką historię Persji do okresu panowania Uzun Hasana, została wydana w Dublinie ${ }^{74}$. W 1733 roku dzieło Krusińskiego ponownie wydał Pemberton.

W 1730 roku w Wenecji ukazało się dwutomowe włoskie tłumaczenie wydawnictwa paryskiego, zatytułowane Storia dell'ultima revoluzione di Persia ${ }^{75}$. Podawana przez Krusińskiego w Prodromus, a także przez bibliografię Backera-Sommervegela informacja o wydaniu The History of the Revolution of Persia w 1728 roku w języku holenderskim wzbudza wątpliwości, ponieważ do tej pory nie udało się odnaleźć tej $\mathrm{książki}^{76}$.

${ }^{71}$ Bibliothèque Nationale de France w Paryżu, rkps Fr. 6834, Charles de Peyssonnel do markiza de Caumont, Sophie, 12 V 1738, k. 81v.

72 J.T. Krusiński, Tragica vertentis..., s. 27.

${ }^{73}$ Idem, The History of the Revolution of Persia..., London 1728.

${ }^{74}$ Idem, The History of the Revolution of Persia..., Dublin 1729.

75 Idem, Storia dell 'ultima revoluzione di Persia..., Venezia 1730.

${ }^{76}$ Por. P. Begheyn, Jesuit Books in the Dutch Republic and Its Generality Lands 1567-1773: A Bibliography, Leiden-Boston 2014, s. 306-307. 


\section{PRZEKŁAD NIEMIECKI: JOSEPH STÖCKLEIN UZUPEŁNIA DU CERCEAU}

Pierwsze wydanie pracy Krusińskiego o historii wojny perskiej zostało opublikowane w języku niemieckim w 1732 roku w serii Neue Welt Bott przez jezuitę Josepha Stöckleina $^{77}$. Ta edycja ma szczególnie duże znaczenie, ponieważ Stöcklein dokonał tłumaczenia, opierając się na edycji francuskiej z 1728 roku oraz łacińskiej, rękopiśmiennej kopii tekstu Judy Tadeusza, którą otrzymał z Wiednia za pośrednictwem jezuity Franza Borgii Teuscha ${ }^{78}$. Do Austrii przywiózł ją z Konstantynopola znany nam już dyplomata cesarski J. Dierling. Przesyłka od Teuscha zawierała również łacińskojęzyczną kopię relacji Durri Efendiego. Informacja ta potwierdza wzmiankę w Prodromus o przekładzie relacji tureckiego dyplomaty jeszcze w czasie pobytu polskiego jezuity nad Bosforem.

Stöcklein uznał, że przekazany mu tekst łaciński o wojnie afgańsko-perskiej jest identyczny z tym, który ojciec Juda Tadeusz przesłał do Paryża. Wydawca Neue Welt Bott, świetnie orientujący się w dorobku edytorskim jezuitów paryskich w zakresie publikacji relacji z działalności misyjnej, uważał ojca Fleuriau za tłumacza na język francuski pracy Krusińskiego. Posiadanie tekstu łacińskiego umożliwiło mu przeprowadzenie badań porównawczych z Histoire de la dernière révolution de Perse. Analiza uzmysłowiła Stöckleinowi zakres interwencji tłumacza francuskiego w tekst łaciński, takich jak zmiany w układzie pracy, wprowadzenie wielu uproszczeń, pominięcie części informacji. Uznał więc, że przygotowując niemieckojęzyczną wersję pracy Krusińskiego, nie może traktować edycji paryskiej w sposób literalny, lecz w możliwie szerokim zakresie powinien wykorzystać kopie łacińskie: opisu wojny afgańsko-perskiej i relacji Durri Effendiego.

Zachowując układ chronologiczny edycji paryskiej, jezuita austriacki dokonał podziału treści na 17 części, które otrzymały tytuły i numery od 384 do 410, jako kolejne składowe całej serii Neue Welt Bott. Obszerna Przedmowa ma numer 394, a przyjęte od Du Cerceau i nieco rozbudowane dzieje rodu Safawidów oraz poszczególnych władców z tej dynastii zostały wydzielone w osobną część (nr 395). Tekst tłumaczenia dzieła Krusińskiego obejmuje kolejnych 12 numerów - od 396 do 408 i niewielki fragment części 409. Pozostały fragment tej ostatniej części wraz z numerem 410 opisuje dzieje wojny od końca roku 1725 do 1730 . Są one tłumaczeniem z Du Cerceau oraz własnym opracowaniem tłumacza. Podział na rozdziały został oparty na łacińskiej kopii pracy jezuity polskiego, wykazuje on bowiem duże podobieństwo do struktury Tragica vertentis, chociaż tytuły poszczególnych części są odmienne. Już nawet pobieżne porównanie treści przekładu francuskiego z niemieckim pozwala dostrzec wyraźne różnice. Stöcklein nie tylko bardziej szczegółowo opisuje

77 J.T. Krusinski, Neuer Welt-Bott oder Allerhand So Lehr-als geistreiche Brief..., Augspurg-Grätz 1732, to wydanie wymieniają: A. Muchliński, op. cit. s. 292; K. Estreicher, op. cit. s. 306; nie podaje go: S.W. Popławski, op. cit.

78 J.T. Krusinski, Neuer Welt-Bott oder Allerhand So Lehr-als geistreiche Brief..., nr 394, s. 1. 
część wydarzeń, ale także wymienia fakty, osoby, nazwy geograficzne i terminy, które nie występują w Histoire de la dernière révolution de Perse. Większość tego typu informacji musiał zaczerpnąć z otrzymanej łacińskiej kopii tekstu Krusińskiego, gdyż odnajdujemy je zarówno w Tragica vertentis, jak i w omówionych poniżej rękopisach wiedeńskich. Przekład Stöckleina jest zdecydowanie bliższy pierwotnej wersji pracy polskiego jezuity niż tłumaczenie Du Cerceau.

\section{„HISTORIA REVOLUTIONIS PERSICAE”: RĘKOPISY WIEDEŃSKIE}

W dotychczasowych badaniach nad twórczością Krusińskiego nie zwrócono uwagi na znajdujące się w zbiorach Biblioteki Narodowej w Wiedniu dwa, pochodzące ze zbiorów Eugeniusza Sabaudzkiego ${ }^{79}$, rękopisy o sygnaturach Cod. 8555 i 8588, noszące identyczny tytuł: „Historia Revolutionis Persicae. Authore P. Juda Krusinsky Soc. Iesu Missionario Persico" ${ }^{80}$. Każdy z rękopisów pisany jest inną ręką, ale układ i treść obu są w zasadzie identyczne. Jedyna różnica to liczący sześć stron (k. 279-281v) suplement w kodeksie 8855, zawierający pominięte przez kopistę akapity 15, 70 i 173, które dopisał na końcu tekstu. Struktura podziału treści „Historia Revolutionis Persicae" jest bardzo podobna do zawartej w dwóch pierwszych częściach Tragica vertentis... Składa się ona z dwóch części podzielonych na kilka rozdziałów, a niektóre z nich zawierają sekcje. Podobnie jak w książce lwowskiej najmniejszą jednostką strukturalną są numerowane akapity. W rękopisach wiedeńskich jest ich 349, a więc o 170 mniej niż w pracy wydanej w 1740 roku. Tytuły poszczególnych części, rozdziałów i sekcji w obu pracach są takie same albo nieco tylko zmienione, na przykład w rękopisie wiedeńskim część druga nosi tytuł „Ipsam rebellionis et belli historiam prosequens”, a otwierający ją rozdział pierwszy „De rebellio et rebellionis origine”, zaś w Tragica vertentis odpowiadające im fragmenty są zatytułowane: „Ipsam belli Persico-Avghanici seriem explicans” i „Rebellium et rebellionis origine". Zawartość treściowa rękopisów odpowiada części pierwszej i drugiej wydawnictwa lwowskiego, co nie oznacza jednak, że jest identyczna, ponieważ zasoby informacji i wiedzy są zdecydowanie większe w Tragica vertentis... Wiedeńska „Historia Revolutionis Persicae” stanowi z całą pewnością pośrednią wersję pracy Krusińskiego, opracowaną na podstawie łacińskiego tekstu wysłanego do Paryża oraz edycji lwowskiej łacińskim tekstem wysłanym do Paryża a edycją lwowską. Wskazuje na to również chronologiczny układ pracy zgodny ze zmianami wprowadzonymi przez Du Cerceau. Wymienione przesłanki pozwalają postawić tezę, że wersja wiedeńska wojny afgańsko-perskiej powstała w czasie pobytu Krusińskiego w Konstantynopolu. Jest to możliwe, jeśli będziemy pamiętać, że już pod koniec lipca 1728 Histoire de la dernière révolution de Perse dotarła do stolicy Turcji,

79 Tabulae codicum manu scriptum praeter graecos et orientalis in Biblioteca Palatina Vindobenensi asservatorum, vol. 5, Wien 1871, s. 270, 305.

80 Österreichische Nationalbibliothek w Wiedniu, Cod. 8555 i Cod. 8588. 
gdzie jezuita wówczas przebywał. Dodać należy, że oba rękopisy to czystopisy niezawierające not proweniencyjnych, marginaliów, przekreśleń i poprawek.

Jak już wyżej wspomniano, Stöcklein, przygotowując edycję niemiecką, korzystał z łacińskiej kopii wojny afgańsko-perskiej ojca Judy Tadeusza. Uzasadnione więc jest pytanie, czy był to jeden z wymienionych z rękopisów znajdujących się dziś w Bibliotece Narodowej w Wiedniu. Informacje Stöckleina na temat otrzymanego odpisu są zbyt lakoniczne, aby odrzucić możliwość korzystania z rękopisu wiedeńskiego lub otrzymania tekstu o identycznej strukturze jak ten rękopis. Na obecnym etapie badań nie jestem w stanie w sposób jednoznaczny na nie odpowiedzieć, ponieważ wymaga to szczegółowych badań komparatystycznych i językoznawczych.

\section{RĘKOPIS BIBLIOTEKI KÓRNICKIEJ}

Jak już wyżej wspomniano, S. Brzeziński odnalazł w zbiorach rękopisów biblioteki w Kórniku polskojęzyczny tekst zatytułowany „Wiadomości o rewolucji perskiej od W.X. Krusińskiego S.I. w Ispahan i od innych zebrane"81. Uznał, że nie jest on pisany ręką Krusińskiego, lecz ,jednego z jego jezuickich konfratrów, który, jak sam zaznaczył w przedmowie, rzecz tę odpisał, a zatem nie przełożył, a po prostu przepisał z innego niewiadomego oryginału polskiego" ${ }^{82}$. Zdaniem Brzezińskiego rękopis różni się zarówno tytułem, jak i treścią od wszystkich wydań łacińskich i obcojęzycznych prac ojca Judy Tadeusza. Rękopis ten nie wzbudzał większego zainteresowania badaczy Orientu. Dopiero kilka lat temu stał się on podstawą dla artykułu S.W. Popławskiego. Badacz ten zgodził się z poglądami Brzezińskiego i wzmocnił jego argumentację, cytując fragment ze wstępu poprzedzającego „Wiadomości o rewolucji perskiej”, w którym anonimowy kopista pisał: „niczym jednak nie odstąpiłem autentyku Xa Krusińskiego"83. Przedstawiona przez obu autorów teza, że tekst w rękopisie kórnickim stanowi odpis oryginalnej, napisanej przez Krusińskiego w języku polskim historii rewolucji afgańskiej, jest jednak nie do utrzymania, jeśli źródło to poddamy bardziej szczegółowej analizie i porównamy z innymi wydaniami jego pracy. Już w samym nagłówku do wstępu anonimowy twórca podaje: „Te wiadomości o rewolucji perskiej X. Krusińskiego SI w różnych językach przez druk wydane w samym tylko ojczystym dla czego dotąd ogłoszone nie są, ja sądzić nie śmiem [...]. W edycji niemieckiej taka jest dana przedmowa" ${ }^{84}$, a dalej ją przytacza. Wszystko, co zawiera wstęp, nie pochodzi zatem od kopisty, lecz jest tłumaczeniem tekstu napisanego w języku niemieckim. W tym języku pracę jezuity polskiego wydał jedynie Stöcklein. Podział na części i rozdziały wraz z ich tytułami oraz treść rękopisu polskiego odpowiadają niemieckojęzycznej wersji opublikowanej w Neuer Welt-Bott. Nawet

\footnotetext{
${ }^{81}$ Biblioteka PAN w Kórniku, rkps 140.

${ }^{82}$ S. Brzeziński, op. cit., s. 53.

${ }^{83}$ Biblioteka PAN w Kórniku, rkps 140, k. 3; S.W. Popław ski, op. cit., s. 115.

${ }^{84}$ Biblioteka PAN w Kórniku, rkps 140, k. 3.
} 
przytoczony powyżej nagłówek to parafraza pierwszych zdań z wstępu Stöckleina, w którym tłumacz zamienił łacinę na język ojczysty. Przekład polski, mimo że zawiera liczne skróty i opuszczenia, wiernie oddaje język i treść pracy niemieckiego autora-tłumacza. Rękopisu kórnickiego nie można więc uznać ani za polskojęzyczne dzieło Krusińskiego, ani za jego oryginalną pracę, gdyż stanowi jedynie przerobione, polskie thumaczenie edycji Stöckleina.

Podsumowując niniejsze badania dotyczące powstania, przeróbek i tłumaczeń tekstów Krusińskiego, można wysnuć następujące wnioski:

- Nieznany jest pierwotny, łacińskojęzyczny tekst historii Krusińskiego, który został zredagowany w Rzymie najpóźniej na przełomie roku 1726 i 1727. Tę pierwszą wersję sam autor nazywał najczęściej Historia revolutionis persi$c e^{85}$ i to ona została wysłana do Paryża.

- Czytelnicy w oświeconej Europie mieli możliwość zapoznania się z dziejami upadku Safawidów opracowanymi przez Krusińskiego za pośrednictwem skróconego i przerobionego thumaczenia francuskiego, które szybko doczekało się przekładów na język angielski i włoski.

- Najbardziej zbliżona do wersji pierwotnej jest niemieckojęzyczna parafraza dokonana przez Stöckleina, który oparł się na łacińskim rękopisie (być może na wersji podobnej do znajdującej się obecnie w bibliotece wiedeńskiej) i edycji francuskiej z 1728 roku.

- Na potrzeby edycji tureckojęzycznej Krusiński dokonał nowej redakcji tekstu łacińskiego, dostosowanej do odbiorcy. Wobec odmiennych interpretacji, głównie w historiografii polskiej i tureckiej, dotyczących osoby tłumacza na język turecki zagadnienie to wymaga dalszych szczegółowych badań.

- Finalną pracą Krusińskiego jest wydana w 1740 roku książka Tragica vertentis. Jej opracowanie przebiegało przynajmniej na trzech etapach. Pierwszym było opracowanie tekstu przesłanego do Paryża. Następnie, po wydaniu francuskojęzycznej parafrazy, jezuita dokonał zmiany układu chronologicznego i ten etap, realizowany zapewne w Konstantynopolu w drugiej połowie 1728 roku, znalazł odbicie w rękopisach wiedeńskich. Ostateczna redakcja tekstu, znacznie poszerzona, nastąpiła w latach 1734-1739.

${ }_{85}$ J.T. Krusińki, Tragica vertentis..., s. 254. 


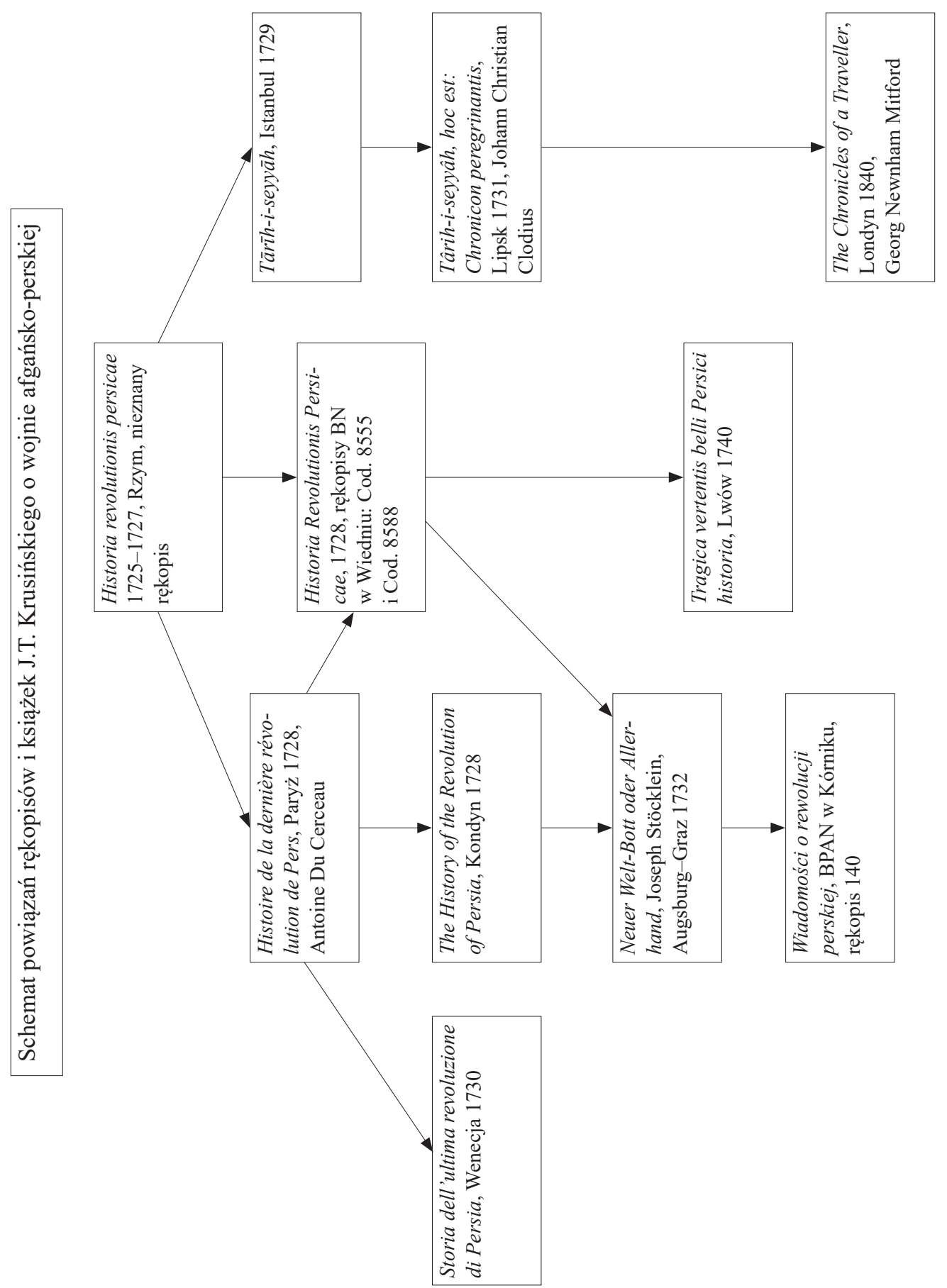




\section{BIBLIOGRAFIA}

\section{Źródła rękopiśmienne}

Biblioteka PAN w Kórniku, rkps 140.

Bibliothèque nationale de France, rkps Fr. 6834.

Österreichische Nationalbibliothek w Wiedniu, Cod. 8555 i 8588.

\section{Źródła drukowane}

Histoire de Thamas Kouli-Kan, Sophi de Perse, contenant une relation exacte de tout ce qui s'est passé dans son expédition contre le Grand-Mogol, Amsterdam-Leipzig 1741.

„Journal de Trévoux” 1728, September.

„Le Journal des sçavans” 1728 Novembre, 1730 Janvier.

Krusiński J.T., The Chronicles of a Traveller, or a History of the Afghan Wars with Persia, in the Beginning of the Last Century, from Their Commencement to the Accession of Sultan Ashruf. Being a Transaltion of "Tareekh-i-Seeah from the Latin of. J.C. Clodius by Georg Newnham Mitford Esq. To Which is Addad, a Brief Account of the Afghan Usurpation, Till Its Overthrow by Tahmasp Koolly Khan, London: James Ridgway 1840.

Krusińs ki J.T., Histoire de la dernière révolution de Perse, t. 1-2, Paris, Briasson 1728; La Haye, Gosse et Neulme 1728.

Krusińs ki J.T., Histoire de la dernière révolution de Perse. Depuis le commencement de ce Siécle jusqu'à la fin de l'Usurpateur Aszraff, t. 1-2, Paris, Briasson 1742.

Krusiński J.T., The History of the Revolution of Persia: Taken from the Memoirs of Father Krusinski Procurator of the Jesuits at Ispahan; who lived Twenty Years in that Country, was employ'd by the Bishop of Ispahan, in his Negotiations at the Persian Court, for the Emperor and King of France; ad was familiarly conversant with the greatest Men of alt Parties. Done into English, from the Original, just publish'd with the Royal Licence at Paris, By Father Du Cerceau, Who has prefix'd a Map of Persia, and a short history of the Sophies; with curious remarks on the account given by Tavernier, Sir John Chardin, and other Writers that have treated particularly of the Government and Country, etc. In Two Volumes, London, J. Pemberton 1728.

Krusiński J.T., The History of the Revolution of Persia: Taken from the Memoirs of Father Krusiniski Procurator of the Jesuits at Ispahan; who lived Twenty Years in that Country, was employ'd by the Bishop of Ispahan, in his Negotiations at the Persian Court, for the Emperor and King of France; ad was familiarly conversant with the greatest Men of alt Parties. Done into English, from the Original, just publish'd with the Royal Licence at Paris, By Father Du Cerceau, Who has prefix'd a Map of Persia, and a short history of the Sophies; with curious remarks on the account given by Tavernier, Sir John Chardin, and other Writers that have treated particularly of the Government and Country, etc. To which is added, a short view of the antiet history of Persia, to the time of Usum Cassan, not in the London edition, Dublin, S. Powell 1729.

Krusinski J.T., Neuer Welt-Bott oder Allerhand So Lehr-als geistreiche Brief, Schrifften und Reis-Beschreibungen: welche von denen Missionariis der Gesellschaft Jesu aus Weit-entfernten Ländern biß Anno 1730. in Europa angelangt seynd. Jetzt zum erstenmal verteutscht und vielfaltig verbessert von P. Josepho Stöcklein, gedachter Societät Priestern 
Achtzehender Theil. Von numero 394. biß numero 410. Begreifft in sich R.P. Judae Thaddaei Krusinski è S.J. und des Herrn Durri Effendi, Nachrichten von der letzten Unruhe in Persien, Augspurg-Grätz 1732.

Krusiński J.T., Pragmatographia de legitimo usu ambrozji tureckiej: To jest opisanie sposobu należytego zażywania kawy tureckiej przez X. Thadeusza Krusińskiego S.J. missionarza perskiego. Rzecz z rękopisma jego wybrana i do druku podana [przez J.E. Minasowicz], Warszawa 1769.

Krusiński J.T., Prodromus ad historiam revolutionis Persicae seu legationis Fulgide Porte ad Persarum Regem Szach Sofi Hussein Anno D. 1720 expeditae relatio, quam redux e perside legatus Durri Effendi turcarum Sultano Achmed III in scripto consignavit. Ex Turcico Latine facta opera P. Judae Thadaei Krusinski Soc. Jesu, Leopoli 1733.

Krusiński J.T., Prodromus ad tragicam vertentis belli historiam seu relatio turcico-persicae legationis. Quam ad Persarum Regem Szah Sultan Hussein Durry Effendi solemniter administravit et redux è Perside Turcarum Imperatori Achmet III in scripto consignavit, ex turcico latine facta [w:] J.T. Krusiński, Tragica vertentis belli Persici..., Leopoli 1740.

Krusiński J.T., Prodromus ad tragicam vertentis belli Persici historiam seu Legationis a Fulgida Porta ad Sophorum Regem Szach Sultan Hussein anno 1720 expeditae autentica relatio quam redux e Persidae Legatus Durri Effendi Turcarum Imperatori Achmet III in scripto consignavit. Ex Turcico additis scholiis, Latine facta opera P. Judae Krusiński Soc. Jesu; Accessit ejusdem De Legationibus Polono-Persicis dissertation, Leopoli 1734.

Krusiński J.T., Storia dell'ultima revoluzione di Persia. Con il compendio della Storia de' Sofi e con riflessoni politiche. Tradotta dal orginale stampato in Parigi, Venezia 1730.

Krusiński J.T., Tārīh-i seyyāh der beyān-ı zuhūr-ı Afğānīyan ve sebeb-i inhidām-i binā-i devlet-i şāhān-1 Safevīyān [Istanbul 1142/1729].

Krusiński J.T., Tārīh-i seyyāh hoc est: Chronicon peregrinantis seu historia ultimi belli Persorum cum Aghwanis gesti, a tempore primae eourum in Regnum Persicum irruptionis eisuque occupationis, usque ad Eschrafum Aghwanum. Persiae Regem continuatam, ex codice Turcico, in officina typographica recenti Constantinopolitana impresso, versa ac notis quisbusdam illustrate, cum Tabula Imperatorum Familae Othmanicae, ex codice manuscripto Turcico, in fine adiecta. Studio et opera Joh. Christ. Clodii, Lipsiae 1731.

Krusiński J.T., Tragica vertentis belli Persici historia per repetitas clades, ab anno 1711 ad annum 1728-vum continuata: Post Gallicos, Hollandicos, Germanicos ac demum Turcicos authoris typos auctior. Authore Patre Thadaeo Krusinski Societatis Jesu Missionario Persico accessit ad eandem Historiam Prodromus iteratis typis Subjectus, Leopoli 1740. „Mercure de France” 1728, Septembre.

\section{Opracowania}

Abrahamowicz Z., Hopp L., Rákóczi és török könyvnyomtatás, „Magyar Könyvszemle” 1977, vol. 93, nr 2, s. 178-181.

Allen W.E.D., The Sources for G. Delisle's 'Carte des Pays Voisins de la Mer Caspiene' of 1723, „Imago Mundi” 1956, t. 13, s. 137-150.

Babinger F., ,, 18. Yüzyılda Istanbul'da Kitabiyat”. Müteferrika ve Osmanlı Matbaası, ed. N.K.Burçoğlu, M. Kiel, Istanbul 2004.

Babinger F., Stambuler Buchwasen im 18. Jahrhundert, Leipzig 1919.

Baranowski B., Znaczenie relacji Tadeusza Krusińskiego dla historii Gruzji pierwszej potowy XVIII wieku, „Folia Historica” 1981, 10, s. 21-33. 
Baranowski B., Baranowski K., Polaków kaukaskie drogi, Łódź 1985.

Begheyn P., Jesuit Books in the Dutch Republic and Its Generality Lands 1567-1773: A Bibliography, Leiden-Boston 2014.

Beydilli K., Müteferrika ve Osmanli Matbaası 18. Yüzyılda İstanbul'da Kitabiyat, „Toplumsal Tarih" 2004, nr 128, s. 44-52.

Bibliothèque des écrivains de la compagnie de Jésus, t. II, par A. de Backer, A. de Backer, C. Sommervogel, Liége-Lyon 1872.

Boogert M.H. van den, The Sultan's Answer to the Medici Press? Ibrahim Müteferrika's Printing House in Istanbul [w:] The Republic of Letters and the Levant, eds. A. Hamilton, M.H. van den Boogert, B. Westerweel, Leiden 2005, s. 265-293.

Borkowski M.P., The Writings of Tadeusz Juda Krusiński's and the Image of Iran in Some 18th Century Polish Printed Geographical Compendia [w:] Irān va Lahestān. Munāsabāt-e farhangi va tamaddoni / Historical and Cultural Interactions of Poland and Iran, eds. D. Kołodzi ejczyk, H. Kazemzadeh, Tehran 1396/2016, s. 15-25.

Brzeziński S., Misjonarze i dyplomaci polscy w Persji w XVII i XVIII wieku, Potulice 1935 (odbitka z „Annales Missiologicae” 1935, t. 7).

Chwaściński B., Hindukusz. Dzieje poznania, „Taternik” 1962, nr 2-4, s. 57-86.

Ciborowska-Rymarowicz I., Orientalista Tadeusz Krusinski (1675-1757) i egzemplarze jego prac w bibliotekach klasztornych i prywatnych XVIII wieku, „Bibliotekarz Podlaski” 2015, t. 16, nr 1, s. 11-34.

Erginbaş V., Enlightenment of the Ottoman Context: İbrahim Müteferrika and His Intellectual Landscape [w:] Historical Aspects of Printing and Publishing in Languages of the Middle East, ed. G. Roper, Leiden-Boston 2014, s. 53-100.

Estreicher K., Bibliografia Polska, t. XX, Kraków 1905.

Fedirko J., Afganistan w polskich badaniach naukowych, „Krakowskie Studia Międzynarodowe" 2007, nr 1, s. 211-236.

Fedirko J., Pierwszy informator Europy o Afganach. Ojciec Tadeusz Krusiński: krakowski uczony, misjonarz, „Alma Mater” 2007, nr 93, s. 83-86.

Gencer Y., Ibrahim Müteferrika and the Age of the Printed Manuscript [w:] The Islamic Manuscript Tradition: Ten Centuries of Book Arts in Indiana University Collections, ed. Ch. Gruber, Indiana University Press 2009, s. 155-193.

Gerçek S.N., Türk Matbaaciliği I. Müteferrika Matbassi, Instanbul 1939.

Hammer J., Geschichte des Osmanischen Reiches: grossentheils aus bisher unbenützten Handschriften und Archiven, vol. 7: Vom Carlowiczer Frieden bis zum Frieden von Kainardsche 1699-1739, Pesth 1835.

Janocki J.D., Lexicon derer itztlebenden Gelehrten in Polen, t. II, Breslau 1755.

Kolbaja D., Juda Tadeusz Krusiński - misjonarz, uczony dyplomata. Życie i dzieło, „Pro Georgia" 1992, z. 2, s. 19-27.

Köpeczi B., A bujdosó Rákóczi, Budapest 1991.

La Mamie de Clairac L. A. de, Histoire de Perse, depuis le commencement de ce siècle, t. 1-2, Paris 1750 .

Lockhart L., The Fall of the Safavi Dynasty and the Afghan Occupation of Persia, London 1958.

Matthee R., Introduction [w:] J.T. Krusinski, The History of the Revolution of Persia: An Eyewitness Account of the Fall of the Safavi Dynasty, Tauris 2018, s. VII-XVII.

Matthee R., Persia in Crisis: Safavid Decline and the Fall of Isfahan, London-New York 2012.

Mermutlu B., The Politic Meaning of Ottoman Printing House, „Uludağ Üniversitesi Fen-Edebiyat Fakültesi Sosyal Bilimler Dergisi” 2008, vol. 15, s. 297-318.

Muchliński A., Materiały do dziejów kościoła polskiego z języków wschodnich, „Pamiętnik Religijno-Moralny” 1861, t. 31, nr 8, s. 134-151, nr 9, s. 289-302. 
Natoński B., Krusiński Jan Tadeusz [w:] Polski Słownik Biograficzny, t. 15, Wrocław 1970, s. 426-428.

Péric aud M.A., Essai sur la vie et les écrits de Du Cerceau, Lyon 1828.

Popławski S.W., Wielki nieznany - o. Tadeusz Krusiński S.J. - misjonarz, dyplomata, pisarz, uczony, „Studia Bobolana” 2015, t. 2, s. 105-126.

Reychman J., Znajomość i nauczanie języków orientalnych w Polsce, Wrocław 1950.

Sabev O., İbrahim Müteferrika ya da İlk Osmankı Matabaa Serüveni (1726-1746). Yeniden Değerlendirme, Istanbul 2006.

Sabev O., İbrahim Müteferrika ya da Ilk Osmankı Matabaa Serüveni (1726-1746). Yeniden Değerlendirme, Istanbul 2016.

Sabev O., Political and Mental Borders: Austrian-Ottoman Relations in the First Half of the Eighteenth Century and the First Ottoman-Turkish Printing Press [w:] Kommunikation und Information im 18. Jahrhundert Das Beispiel der Habsburgermonarchie, Hrsg. J. Rimmel, M. Wögerbauer, Wisbaden 2009, s. 91-99.

Sabev O., Portrait and Self-Portrait: Ibrahim Müteferrika's Mind Games, „Osmanlı Araştırmaları. The Journal of Ottoman Studies” 2014, vol. 44, s. 99-121.

Schwab M., Bibliographie de la Perse, Paris 1875.

Skowron R., La contribución de Tadeusz Krusiński S.I. al conocimiento de Persia y del Cáucaso en Europa. La circulación de la información y propiedad intelectual en el siglo XVIII [w:] Eastern Europe, Safavid Persia and the Iberian World: Frontiers and Circulations at the Edge of Empires, eds. J. Cutillas Ferrer, O. Recio Morales, Valencia 2019, s. 59-79.

Tabulae codicum manu scriptum praeter graecos et orientalis in Biblioteca Palatina Vindobenensi asservatorum, vol. 5, Wien 1871.

Toderini G., Lettaratura Turchesca, vol. III, Venezia 1787.

Touzard A.M., French Travelers in Persia, 1600-1730, Encyclopaedia Iranica, 2016, http://www.iranicaonline.org/articles/france-vii-french-travelers-in-persia-1600-1730 (dostęp: 30.12.2012).

Watson W.T., Ibrahim Müteferrika and Turkish Incunabula, „Journal of the American Oriental Society" 1968, vol. 88, no. 3, s. 435-441.

Załęs ki S., Jezuici w Polsce, t. III, cz. II, Lwów 1902.

Załęski S., Misje w Persji w XVII i XVIII wieku pod protektoratem Polski, Kraków 1882.

Zenker J.T., Bibliotheca orientalis. Manuel de bibliographie orientale, vol. 1, Leipzig 1846.

Zieliński F., Xsiądz Krusiński. Wiadomości historyczne, „Biblioteka Warszawska” 1844, t. 4, s. 375-397. 